позбутись хибних стереотипів, а головне у інтерактивній, цікавій, сучасній та не нав'язливій формі сформувати знання та уміння по роботі з сім'ями, які опинилися в складних життєвих обставинах та самостійно не в змозі вирішити свої проблеми.

\title{
Література:
}

1. Бєлоліпцева О. В. Соціально-педагогічна робота з сім'ями, які опинилися в складних життєвих обставинах / Бєлоліпцева О. В.// Науковий вісник Чернігівського державного педагогічного університету : зб. наук. пр. / [гол. ред. М. О. Носко]. - Чернігів : ЧДПУ, 2011. - Вип. 84. Педагогічні науки. - С. $19-21$.

2. . Гендерночутливий підхід у роботі з вразливими верствами населення у соціально-правовій сфері: навчал.-метод. посіб. / Упор. Бєлоліпцева О.В, Лисенко Ю. О., Ткаченко М. Є., Чернецька Ю. І., Цибуліна І. В. ; за заг. ред. О.І.Рассказової. - Х. : ХГПА, 2017. - 78 с.

3. Закон України «Про соціальні послуги» [Електронний ресурс]. Режим доступу : http: // zakon 1. rada.gov.ua.

DOI https://doi.org/10.30525/978-9934-26-114-5-31

\section{ВІТЧИЗНЯНИЙ ТА ЗАРУБІЖНИЙ ДОСВІД РЕАЛІЗАЦІї ПРИНЦИПУ СТУДЕНТОЦЕНТРИЗМУ}

\author{
Борисенко А. О. \\ аспірант \\ Миколаӥвський національний університет імені В. О. Сухомлинського \\ Науковий керівник: Якименко С. I. \\ доктор філософії в галузі освіти, професор, \\ завідувач кафедри початкової освіти \\ Миколаӥвський національний університет імені В. О. Сухомлинського \\ м. Миколаїв, Україна
}

Сучасні реалії створюють передумови на ринку освітніх послуг вітчизняних навчальних закладах, що потребують трансформації системи внутрішнього забезпечення якості освіти, у тому числі на основі вивчення та адаптації ефективного іноземного досвіду. Ключовим аспектом аналізу особливостей розвитку сучасної освітньої системи є студентоцентризм. 
Перш за все важливо брати до уваги, що студентоцентризм є досить складне, багатопланове явище i процес. «Студентоцентризм - це активна реакція освітянського середовища на мінливі потреби ринку праці, потреби формування загальних і фахових компетентностей, необхідних не лише для якісного виконання професійних обов'язків, а й для розв'язання життєвих проблем, ситуацій, нагальних проблем державотворення». Основна мета студентоцентризму - створення сприятливих умов для якісного засвоєння знань, формування професійних умінь і навичок, компетентностей, при збереженні свобод здобувачів вищої освіти для досягнення культурних і освітніх цілей [3].

Не беручи до уваги зовнішні фактори, такі як відмінність в оплаті праці виткладачів, умови навчання в Україні та США доцільно зосередитись лише на подібних та відмінних основах навчання [1, с. 16]. Так, в українських університетах, для успішного функціонування принципу студентоцентризму, слід змінити психологію щодо ролі двох ключових елементів вищої освіти, а саме студентів i професорсько-викладацького складу. Зважаючи на те, що саме за рахунок студентів здійснюється фінансування вищих навчальних закладів, у більшості країн світу, у тому числі й США, студенти мають право обирати університети та відповідні дисципліни до вивчення, що не залежить від навчальної програми (вони більш-менш стандартизовані по всьому світу), а залежно від обізнаності та особистих якостей професорсько-викладацького складу. Через це, в пріоритеті є потреби професорсько-викладацького складу [9].

Наступний аспект, що варто брати до уваги $є$ те, що студенти як цільова аудиторія мають отримати ширші можливості та брати участь в оцінці якості роботи викладачів, а саме на основі анонімного анкетування після завершення дисципліни (курсу). Це є досить небезпечним, адже студент може помститися вибагливому викладачу, тому в університетах США анонімне анкетування поєднується 3 відвідуванням занять спеціально призначеними особами, основними функціями яких і полягають у забезпеченні об'єктивності оцінювання рівня викладання.

Також на студентів мають вагомий вплив саме здобутки викладачів, тому різного роду заохочення та умови збереження посад професорсько-викладацьким складом, у першу чергу це охоплюють академічну активність (публікації відповідного рівня), міжнародний досвід і налагодження співпраці з представниками бізнес структур [5, c. 103]. 
Наступним є те, що власне студенти мають бути залучені до формування програм дисциплін, а також і працедавці, що матимуть вплив на матеріал, який засвоюють майбутні працівники [7, с. 43].

Також свої особливості має поширення студентоцентризму в європейських країнах. Згідно Дж.Т. Клейн [8, с. 87]. студентоцентризм має значний вплив на те, як ми сприймаємо процес навчання. Студентоцентризм (існував ще при Сократу і змінювався протягом історії) має давнє походження. Акцент в ньому робиться на активне, а не на пасивне навчання: упор на поглиблене вивчення предмета і його розуміння; збільшення рівня відповідальності студента; установка на самостійність студента; взаємозалежність між викладачем і студентом; взаємна повага між викладачем і студентом; рефлексивний підхід до процесу навчання як з боку викладача, так і того, хто навчається [2, с. 60].

Документи, прийняті на Среванській конференції (2015р.), визначили чіткий зв'язок між студентоцентризмом і забезпеченням i підвищенням якості освіти. Цей зв'язок особливо помітний в переглянутих ЕСР5. Міждисциплінарні програми можуть використовувати для студентоцентризму для:

- підтримки ефективного та активного навчання;

- спрощення різних способів навчання;

- розвитку автономії і самостійності учня;

- зосередження уваги на навичках і практичної діяльності, що забезпечують навчання протягом усього життя і самостійність у вирішенні проблем;

- побудови програми навчання з використанням методів педагогіки конструктивізму;

- використання проміжного контролю 3 метою забезпечення динаміки процесу навчання.

Група високого рівня 3 модернізації вищої освіти в «Звіті для Європейської комісії про поліпшенні якості викладання і навчання в вищих навчальних закладах Європи» розробила плани щодо поліпшення якості викладання і навчання і висловила думку про те, що на студентоцентризм має бути покладено в основу розвитку програм навчання: «Вищі навчальні заклади повинні вводити і розробляти крос, транс-і міждисциплінарні підходи до викладання, навчання i його оцінкою, допомагаючи студентам розвивати розуміння і підприємницький, прогресивні типи мислення» [10].

Міждисциплінарні програми стають стимулом для вдосконалення програм навчання і розвитку нових методів викладання, відображають затребувані серед європейських роботодавців навички і професійні 
якості, наприклад, навички вирішення проблем, вміння працювати в команді.

Професор Орла Філі, голова наукової ради Ірландії, підтримує розвиток міждисциплінарних програм на всіх рівнях освіти: «... нам потрібно підтримувати ідею про те, що міждисциплінарність може поліпшити результати навчання. Елементи міждисциплінарного навчання повинні вводитися на всіх рівнях освіти для того, щоб спонукати студентів поєднувати різні предмети і застосовувати отримані знання в інших областях. Це послужить їх інтересам і підготує до різноманітності життєвих викликів» [4].

Щодо поширення використання принципу студентоцентризму в Україні, варто зазначити, що протягом останніх років ситуація значно покращилась, серед ВНЗ, коледжів та технікумів в Україні, однак, звичайно вона ще не досягла бажаного рівня.

Таким чином, розвиток студентоцентризму є дуже важливим й має вагомий вплив на розвиток процесу навчання. Власне навчання сприяє активній участі студента, і прагне прищепити студентам радість від навчання як у закладі так і поза його межами.

\section{Література:}

1. Авшенюк Н. М. Транснаціональні імперативи розвитку вищої освіти у XXI столітті: прогнози і перспективи. Вісник Черкаського університету. Серія «Педагогічні науки». 2012. № 1. (214). С. 19-23.

2. Галан О.М. Студентоцентризм як системоутворювальний принцип підготовки майбутніх соціальних працівників у контексті сучасних освітніх викликів. Вища школа. 2020. №1. С.58 - 72 .

3. Ільченко А.М. Студентоцентризм як базовий принцип організації освітнього процесу у вищій школі URL: http://dspace.pdaa.edu.ua:8080/ bitstream/123456789/8105/1/Тези\%20Ільченко\%20A.M..pdf

4. Ковалюк Т. В. Моделювання розвитку вищої освіти на базі компетентнісного підходу та особистісно орієнтованих освітніх траєкторій. Інформаційні технології $і$ засоби навчання. 2017. № 5. T. 61. C. 245-260.

5. Космачева Л.М. Студентоцентрированое образование как условие реализации основних образовтельных програм ВПО. Педагогика професіонального образования. 2012. № 2. С. 101-104.

6. Мартинчук О. В. Студентоцентрований підхід до підготовки фахівців 3 інклюзивного навчання дітей 3 особливими освітніми потребами. Актуальні питання корекційної освіти. 2015. № 5. Т. 1. C. 203-218. 
7. Токарь В.В. Студентоцентризм у системі внутрішнього забезпечення якості вищої освіти: імплементація в Україні досвіду університетів США. Збірник матеріалів всеукраӥнської науково-методичної конференції за участю міжнародних представників. 2016. С. 43-44.

8. Klein, J. T. Interdisciplinarity: History, Theory and Practice. Detroit, $1990.214 \mathrm{p}$.

9. Hurynovich T.Student-centered approach in foreign language teaching / Hurynovich T URL: https://elib.bsu.by/bitstream/123456789/ 189930/1/Hurynovich\%20T._STUDENT-CENTERED\%20APPROACH\% 20IN\%20FOREIGN\%20LANGUAGE\%20TEACHING.pdf

10. Report to the European Commission on Improving the quality of teaching and learning in Europe's higher education institutions URL: http:// ec.europa.eu/education/library/reports/modernisation_en.pdf.

DOI https://doi.org/10.30525/978-9934-26-114-5-32

\title{
ВИКОРИСТАННЯ ІНФОРМАЦІЙНО-КОМУНІКАЦІЙНИХ ТЕХНОЛОГІЙ НА ЗАНЯТТЯХ 3 ІНОЗЕМНОЇ МОВИ
}

\author{
Борін К. А. \\ доцент кафедри викладання другої іноземної мови \\ Запорізький національний університет \\ м. Запоріжжя, Україна
}

Іноземна мова у сучасному світі $є$ важливим засобом міжкультурного спілкування, який сприяє вербальному порозумінню громадян різних країн та забезпечує такий рівень культурного розвитку людини, який дозволяє вільно орієнтуватись і комфортно почувати себе у країні, мова якої вивчається.

Дуже потужним інструментом у методичному арсеналі викладача на заняттях 3 іноземної мови виступають інформаційно-комунікаційні технології, які поєднують у собі все, що сучасна людина створює під час технічного прогресу. Перш за все, це персональні комп'ютери, ноутбуки, нетбуки, планшети (також графічні), смартфони, електронні книги, проектори, медіа-дошки тощо. Окрім вищезазначених електронних пристроїв слід звернути увагу на глобальну мережу Інтернет та, пов'язаними 3 ним, соціальні мережі, платформи інформаційного забезпечення для дистанційного навчання або суто навчальні матеріали, що знаходяться у вільному доступі для студентів [4]. 